\title{
IAMJ
}

INTERNATIONAL

AYURVEDIC

MEDICAL JOURNAL

ISSN: 2320-5091

Impact Factor: 6.719

\section{AYURVED MANAGEMENT OF SECONDARY INFERTILITY - A CASE STUDY}

\author{
Sujata. Biradar ${ }^{1}$, Asha $^{2}$ \\ ${ }^{1}$ MS (AYU), Assistant Professor, Dept. of Prasooti Tantra and StreeRoga \\ BVVS Ayurveda Medical College and Hospital Bagalkot, Karnataka, India \\ ${ }^{2} \mathrm{MD}$ (AYU), Assistant Professor, Dept. of Panchakarma \\ BVVS Ayurveda Medical College and Hospital Bagalkot, Karnataka, India
}

Corresponding Author: drashaanandd@gmail.com

https://doi.org/10.46607/iamj2709032021

(Published online: March 2021)

Open Access

(C) International Ayurvedic Medical Journal, India 2021

Article Received:20/02/2021 - Peer Reviewed:02/03/2021 - Accepted for Publication:10/03/2021

D) Check for updates

\begin{abstract}
Infertility due to anovulatory cycles over recent years, has emerged as one of the most common health issues that many young women have been facing. Sedentary lifestyles with minimum physical activity, rising stress level and irregular sleep pattern are few of the reasons, according to many clinicians and health experts. PCOD is a common Endocrine disturbance affecting females of age group between 15-30 years. The disorder accounts for delayed periods, Infertility, obesity hirsutism and acne. According to modern science exact cause of disease is unknown. In Ayurveda all diseases of female reproductive system are classified under Yonivyapada, according to Ashtanga Hridayam 20 diseases of Vagina arises because of faulty food habits. PCOD is a kapha predominant disorder; kapha gets aggravated by consuming more sleshmika and sneha containing food items and by lethargic lifestyle. The line of treatment in modern medicine is Harmonal therapy. In Ayurveda the line of treatment is according to dosha predominance, here it is kaphahara, Strotoshodhaka and Anulomana. So, in the present study - Classical Virechana, Pushpadhanwa rasa, KanchanaraGugglu, Triphalvati, are selected. The result is outstanding, and symptoms subsided. Further clinical trials can be conducted to prove the efficacy of the drugs statistically.
\end{abstract}

Keywords: Infertility, Artavadosha, Shananuoshadi, Shodhana 


\section{INTRODUCTION}

Infertility is defined as a failure to conceive with one or more years of regular unprotected coitus. Primary infertility denotes those patients who have never conceived. Secondary infertility indicates previous pregnancy but failure to conceive subsequently. ${ }^{1,6,7}$ Secondary infertility shares many of the same causes of primary infertility, like Ovulatory dysfunction30$40 \%$, Tubal disease $25-35 \%$, Uterine factors $10 \%$, cervical factors $5 \%$, Pelvic endometriosis $1-10 \%$.In Ovulatory dysfunction PCOD is main cause for anovulatory cycle which leads to infertility ${ }^{6}$.PCOD is a common Endocrine disturbance affecting females of age group between 15-35 years. The disorder accounts for delayed periods, Infertility, obesity and hirsutism. According to modern science exact cause of disease is unknown. It is prevalent in young reproductive age group 20 to $30 \%$. It affects the mental \& physical health of a woman and disturbs her family as well as social life. Ovulatory factor is responsible for $30-40 \%$ cases of infertility. It is heterogeneous endocrine disorder that effect one in 15 women worldwide. Most common causes for infertility are PCOD. It is common endocrine disorder with prevalence ranging from 2.2 to $26 \%{ }^{2}$

Ayurveda is not only medical science, but also it is life science, which gives message of health and better living. Now days because of stressful life and unhealthy food habits infertility become more common in both male and female. More commonly female in reproductive age PCOD is common.

In Ayurveda Kashyapa Samhita explained vadhyatva separately as Apraja (Primary infertility), Sapraja (secondary infertility).

In Ayurveda all diseases of female reproductive system are classified under Yonivyapada. A few diseases in group of yoni vyapad and jataharini have some similarities with this entity but pushpaghni jataharini described by Acharya Kashyap has got much resemblance. PCOD is a kapha predominant disorder; kapha gets aggravated by consuming more sleshmika and sneha containing food items and by lethargic lifestyle. In Ayurveda the line of treatment is according to dosha predominance. Especially panchkarmashodhana treatment are more helpful in treating srotoavrodha by vamana or Virechana. Shodhana procedure helps to kaphahara, Strotoshodhaka and Anulomana. ${ }^{10}$

\section{CASE REPORT}

A female patient aged about 26 years came to OPD of Prasooti Tantra and StreeRoga BVVS Ayurved Medical College and Hospital Bagalkot with chief complaints of Irregular periods, acne on face, and obesity since one year and eager to conceive. Associated Symptoms: Irritation, excessive hunger, lethargic, Heaviness in head, constipation.

History of Present Illness-The patient was apparently normal before one year back, gradually developed irregular menstrual cycle, obesity and from last 4 months acne on face increased, LMP two months back UPT Negative.OBG history $\mathrm{P}_{1} \mathrm{~L}_{1}$ 6years old male child FTND. Investigations, FSH, LH are normal. USG Impression Bilateral Morphological PCOD.

\section{Treatment Protocol}

After obtaining written informed consent. For this case planned for classical Virechana and Shamanuoshadi. Here for shodhanaanga snehapana trihplagritha advised for three days because triphala is tridoshahara, Gritha is pittahara and triphalagrith does karshana action. Sarvangabhayanga with manjistaditaila. Virechana karma with Trivurthalehya. Deepana \& Pachana with chitrakadivati 2 tid for 2 days. After observing proper appetite and bowel movements. Shodhanaanga Snehapana with triphalagritha for 3 days i.e. $1^{\text {st }}$ day $30 \mathrm{ml}, 2^{\text {nd }}$ day $60 \mathrm{ml}, 3^{\text {rd }}$ day $90 \mathrm{ml}$. On $3^{\text {rd }}$ day appearance of smayaka snigdha lakshana. During these days light, warm, and liquid diet is advised. Sarvang Abhyanga and BashpaSweda with Manjistaditaila for 3days, Virechana karma Trivruth avlehya $80 \mathrm{gms}$ with warm water. Total 8 vegas observed. Advice on discharge-Samsarjana karma for two days., After that Shamanoshadi are advised are Tab-Pushpadhanva rasa 1BD, TabKanchanar Guggulu 2BD, Tab- Triphala vati.1BD For 15 days. 


\section{Outcome and Follow-up}

After virechana patients lost weight about $5 \mathrm{~kg}$ and Pimples and dark spots are reduced. Advised follow up after 15 days.

First follow up- She got period on 23/10/2020 having normal bleeding

Advised-Tab-Pushpadhanva rasa 1BD, TabKanchanar Guggulu 2BD, Tab-Triphala vati.1BD for 1 month and USG on third day of next cycle.

Second follow up- Amenorrhea since 1month 7days. UPT -positive. Early Pregnancy Ultrasound ResultSingle Gestational sac and Fetal pole seen, Garbhapal rasa $1 \mathrm{BD}$

\section{DISCUSSION}

Infertility is most common issues nowadays because of food habits and lifestyle. In female PCOD is one of the common causes for infertility. In this case it is secondary infertility because of PCOD. In Ayurveda Samhita have explained very good treatment of choice in infertility and PCOD. Here planned for classical Virechana Karma and Shamnuoshadis. Panchakarma is best treatment of choice for doshanirharana. Here Kapha-Pitta Doshas and medho dhatus are involved. For Kapha and Medha vanama is indicated but Sthana Samshrayain Adhobhaga for this reason selected Virechana Karma. Here Chitrakadi vati is deepaka pachaka, acts on Samana and apana vata,pachaka pitta dosha. Triphala Ghrita is Kapha-vata hara, Rukshana and Medhohara. Manjistaditaila acts on pitta dosha, and Varnya. TrivruthAvalehya is Best Virechaka and does doshanirharana without much complication. As shamanushadi Pushapadhanva rasa balances Vata - pitta dosha, Help regulation of menustrual cycle. Kanchanar Guggulu is KahpaMedha hara, helps in reduction cyst size. Triphalavati is Kapha-vatashamaka and anulomana. By Shodhana and Shamanaushadi Treatment Menstrual cycle becomes regular and next consecutive cycle she conceived.

\section{CONCLUSION}

Infertility is most common nowadays because of lifestyle, and most common cause is PCOD. PCOD other associated complaints like weight gain, pimples over face, mood swing etc. These complaints can be treated with classical virechana and shamanushadis. Marked changes were noticed in the know case Infertility with PCOD of the patient after classical virechana and shamanaushadi. Observed the changes like weight loss about $5 \mathrm{~kg}$, Pimples and dark spots reduced, regular menstrual cycle with normal bleeding. For next consecutive cycle patient conceived.

\section{Declaration of Patient Consent}

Authors certify that they have obtained patient consent form, where the patient care giver has given her consent for reporting the case along with the images and other clinical information in the journal. The patient understand that her name and initials will not be published, and due efforts will be made to conceal her identity, but anonymity cannot be guaranteed.

\section{REFERENCES}

1. https://www.deccanherald.com

2. Sushrutha. Sushruta Samhita with Nibandha Sangraha Vyakhya by Dalhanacharya and Nyayachandrikakhyapanjikavyakhya by Gayadasa,edited by Vaidya Yadavaji Trikamji,8th ed Varanasi: ChaukambhaKrishnadas Academy; 2013. p. 168

3. Agnivesha, Charaka, Dridhabala. In: Charaka Samhita, Sutra Sthana, Vatakalakaliya Adhyaya, 12/8. 4th ed. Jadavaji Trikamji Acharya., editor. Varanasi: Chaukhambha Sanskrit Sansthan; 1994. p. 79.

4. Pandit Hariprasad Tripathi, Harita Samhita, Choukambha Krishnadas Academy, Varanasi, pp 447,448, cp 524.

5. Kasyapa Samhita Edited prof P V Tewari Chaukhambha Visvabharti reprint 2013 Kalpastana chapter 2 p.327

6. Dutta DC. Textbook of Gynaecology Including Contraception. In: Konar H, editor. 7th ed Reprint.Ch 8 and Ch. 15. Calcutta: New Central Book Agency; 2016. P.75and p. 152

7. Shaws textbook of gynaecology 13 editions by V G Padubidri and Shirish N DaftaryElsevier publication Ch 3 and Ch17 p.38 and p.215

8. Ayurvediyaprasutitantra Evam Streeroga part 2 Streeroga by Prof $(\mathrm{km})$ Premavati Tiwari Ch 5 p.286 
9. https:/www.researchgate.net/publication/276415300

10. Principles and practice of Panchakarma by Dr. Vasant. C. Patil Atreya Ayurveda Publication, edition 3, chapter 1-page no. 3

11. Principles and Practice of Panchakarma by Dr. PulakKantiKar, Published by Chukhamba Sanskrit Pratishthan, First edition:2013 Chapter no.5pageno.531.

12. Principles and Practice of Panchakarma by Dr. Pulak KantiKar, Published by Chukhamba Sanskrit Pratishthan, First edition:2013 Chapter no.5-page no.532.

\section{Source of Support: Nil}

\section{Conflict of Interest: None Declared}

How to cite this URL: Sujata. Biradar) \& Asha: Ayurved Management Of Secondary Infertility - A Case Study. International Ayurvedic Medical Journal \{online\} 2021 \{cited March, 2021\} Available from: http://www.iamj.in/posts/images/upload/677_680.pdf 